\title{
ATTRACTING YOUNG TRAVELLERS TO A TOURIST DESTINATION: EXPLORING MILLENNIALS' DREAMS
}

\author{
Dina Lončarić \\ Jasmina Dlačić \\ Aleksandra Pisnik
}

https://doi.org/10.20867/tosee.05.54

\begin{abstract}
Purpose - The purpose of this study is to examine Millennials' selection of future travel destinations especially destinations they dream to visit as well as to identify pull factors that attract them to dream destination. As Millennials are becoming dominant travel segment it is important to explore how they evaluate and based on what characteristics they select their dream destinations they plan to visit.

Design/Methodology - The empirical research aimed to explore Millennials' dream destination. Research framework is based on Morgan and Xu (2009) and Kapferer (2008) research. Also, information seeking patterns of Millennials are explored. Empirical research collected data of 420 European travel Millennials. Results were analysed using qualitative and quantitative research techniques.

Findings - Research results indicate that young travellers prefer to visit countries in South and Mediterranean Europe. Mainly choosing countries that are famous for their physical attributes and cultural interactions. Several pointed out beautiful nature, cultural heritage and sea \& sun. Dream travel destinations are chosen as they offer destination-oriented and socially-oriented attributes. Originality of the research - The paper contributes to understanding Millennials motives for planning future tourist destinations. Also, it contributes to identifying Millennials' perspective in process of selecting future experience as tourists. The research results are valuable to marketing managers in tourist destinations to help them identify future travellers' motives in selecting a tourist destination.
\end{abstract}

Keywords Millennials, tourist motivation, tourist destination

\section{INTRODUCTION}

Contemporary tourism research increasingly addresses young people (Generation Y or Millennials) as a significant segment of the international tourism market. According to UNWTO (2017), youth travel has become the fastest growing segment of international tourism, representing more than $23 \%$ of the over one billion tourists travelling internationally every year. Young consumers, Millennials, are considered to be the travellers of the future (Monaco 2018). They were born in the period between 1977 and 1999 (Lancaster and Stillman, 2003 in Dlačić and Kadić-Maglajlić 2013, UNWTO 2017) and are experience-seekers (Morgan and Xu 2009). Among Millennials, 72\% of them will go on a dream holiday in the near future (Future foundation, 2016) and for them experience is everything they are searching for when planning a future travel. 
ToSEE - Tourism in Southern and Eastern Europe, Vol. 5, pp. 405-417, 2019

D. Lončarić, J. Dlačić, A. Pisnik: ATTRACTING YOUNG TRAVELLERS TO A TOURIST

Different travel patterns, different inspirations and motivations are noticed among Millennials (Future foundation, 2016). They strive for social media presence, are motivated by reducing stress and inspired by experiencing local culture in selecting their dream destinations. Their desire for authentic cultural experiences (ITB 2016) is expressed and are not intimidated by going alone on a holiday. Traditional mass tourism offering will not be dominant in future (Karayilan and Cetin 2016), as new emerging market segments are searching for something different. Millennials, as emerging market segment, are focused on experience, verified authenticity (Millennial travel report, 2016), giving more importance to social media and interactions through them related to their online engagement. Having all this in mind it is evident that Millennials represent new market segment with high potential for tourism.

This represents a challenge for marketing managers in tourism who need to develop marketing strategies to attract this significant market segment. Therefore, in order to attract the Millennials to the destination, it is important to know their behavioural patterns, especially the process of choosing a tourist destination and factors affecting it. In this regard, the objectives of this paper are (1) to explore which destinations Millennials consider as their dream destinations; (2) to determine the pull factors of tourist destinations that the millennials dream about, and (3) to identify ways Millennials search for information and plan their trip.

The article is structured as follows: after the introduction, a brief conceptual framework is given. Following with description of the methodology and the results of the primary research. Finally, there is conclusion, which includes recommendations for managers in tourist destinations as well as recommendations for further research.

\section{CONCEPTUAL FRAMEWORK}

Tourism consumer behaviour can be considered as the ensemble of its acts, attitudes and decisions regarding choosing, buying and consuming tourism products and services, and also its post-consuming reactions (Fratu, 2011). In order to reach its target market successfully, marketing experts in tourism need to know all the phases as well as factors influencing this process. The complexity of the decision-making process in travel planning is a challenge for marketing experts. Namely, consumer behaviour in tourism is characterized by high involvement in the purchase decision, high consumer commitment, strong influence by other people, long-term decision, considerable emotional significance, tourism product and provider of the tourism product, high level of information search and high level of insecurity linked to intangibility (Honer and Swarbrooke, 2016, p. 111). Moutinho (2000, p. 73) states that a vacation tourist behaviour model consists of three parts: (1) pre-decision and decision process; (2) postpurchase evaluation; and (3) future decision-making. Pre-decision and decision-making are of great importance, as the two other phases depend on them. Further, Hyde (2008) elaborates the first phase of the decision-making process and states that "pre-vacation decision-making may be conceptualized as comprising three phases - a search for travel and destination information, the making of a plan for the vacation, and the booking of selected elements of the vacation, such as the means of transport and places of accommodation". 
ToSEE - Tourism in Southern and Eastern Europe, Vol. 5, pp. 405-417, 2019

D. Lončarić, J. Dlačić, A. Pisnik: ATTRACTING YOUNG TRAVELLERS TO A TOURIST

The focus of this paper is the pre-trip phase of travel, which starts by identifying needs, that is, by dreaming about traveling. The question that emerges is which destinations attract young tourists and why? The research carried out by Morgan and Xu (2009) on a sample of British students has shown that the students dream about different destination, mostly about Australia, New Zealand and the Pacific islands, followed by the Caribbean and African countries. Only 2 percent of students dream about Mediterranean countries, while 16 percent did not cite a single destination. When asked about the reason for choosing a specific destination, most $(43.9 \%)$ did not give a reason, or want to see different destinations (Morgan and Xu 2009). In another research Xu, Morgan and Song (2009) have been established that British and Chinese students enjoy beach holidays, and place importance on having fun and relaxing. They are motivated to discover somewhere new and prefer to eat the local food of the destination. Hence, research results are pointing out that there is a need to explore students, that is Millennials, also in other countries.

In the tourism literature a lot of research on motivational factors has been conducted and theories have been developed (eg. Crompton, 1979; Yuan and McDonald, 1990; Uysal and Jurowski, 1994; Turnbull and Uysal, 1995; Oh, Uysal, and Weaver, 1995, Pesonen et al. 2011; Bozic et al. 2017 etc.). In the tourism literature, destinations are considered as the pull factors for tourists (Karayilan and Cetin 2016). These pull factors consist of attractions, facilities, infrastructure, transportation and hospitality (Mill and Morrison 1985 in Cetin and Bilgihan 2016). Starting from Kapferer's brand identity prism (Kapferer 2012), Morgan and Xu (2009) have explored the memorability of tourist experiences and motivational factors that attract young tourists to the destination. Six dimensions were used: (1) physical attributes of a destination, (2) destination image (personality), (3) benefits, (4) meanings, (5) social interactions and (6) cultural interactions. So, destination's external (pull) factors comprise the physical attributes of the destination and destination image (personality) (Morgan and $\mathrm{Xu}$ 2009). The destination image is perceived as the "total impression the destination makes on the mind of tourists" (Morgan and Xu 2009). A destination's internal (push) factors comprise benefits and meanings. Benefits that tourists seek from engaging in tourism activities are the core of motivational studies in the tourism and leisure literature (Otto and Ritchie 1996). Meanings are created by tourists' "memories, interest and concerns as much as by their encounter with the attraction" (Morgan 2008, p.83). Social and cultural interactions are an essential part of tourist experiences. In visiting a tourist destination, social interaction, as a cross-cultural encounter, emerges between tourists and between tourists and the host community (Morgan and Xu 2009). Regarding this, and in relation to focus of our research, factors that attract Millennials into the destination are explored.

The phase of dreaming about travel is followed by the gathering of information. Tourism information search includes internal search and the multiple external information sources used (Ho et al., 2012). Information search is considered crucial to tourists' destination choices (Jacobsen and Munar, 2012). Nowadays, many influences come from new media, especially in the information gathering phase. According to research of $\mathrm{Xu}$, Morgan and Song (2009), the main sources of information for students used in planning the trip are the Internet, and friends and family. Therefore, this research builds on this and extends to explore reasons for using and information seeking patterns. 
ToSEE - Tourism in Southern and Eastern Europe, Vol. 5, pp. 405-417, 2019

D. Lončarić, J. Dlačić, A. Pisnik: ATTRACTING YOUNG TRAVELLERS TO A TOURIST ...

\section{EMPIRICAL RESEARCH}

Objectives of this study are related to exploring Millennials travel patterns related to pretrip phase of the customer journey. That is to identify destinations they consider as their dream destinations and to identify pull factors of the dream destination. Also, objective was to analyse how Millennials search for information in pre-trip phase in order to plan their trip.

Research framework is based on Morgan and Xu (2009) research related to a dream destination that will provide specific tourism experiences, as well it is based on Kapferer (2008) destination identity prism that points out different facets of destination tourism experience. Also, research from Jalilvand, Ebrahimi and Samiei (2013) and Munar \& Jacobsen (2014) was used for identifying travel patterns of information search in pre-trip phase.

Research was conducted during May and June 2017 on purposive sample of Millennial travellers. Online questionnaire was used to collect the data. Questions used in questionnaire were related to identify dream destination of each individual and reasons for dreaming about them. Also, their travel patterns related to pre-trip phase were identified in order to provide suggestions for destination managers. As open questions were used, a qualitative content analysis was applied for analysing data. Quantitative questions were analysed using SPSS version 21.

Data gathering collected 420 usable questionnaires. Hence, respondents profile of these 420 respondents is analysed in Table 1 .

Table 1: Respondents' profile (\%)

\begin{tabular}{|l|c|l|c|}
\hline \multicolumn{3}{|c|}{ CHARACTERISTICS } \\
\hline \multicolumn{3}{|c|}{ Country } & \multicolumn{2}{c|}{ Age } \\
\hline Croatia & 42.9 & Up to 19 years old & 5.5 \\
\hline Austria & 23.3 & $20-25$ & 67.6 \\
\hline Poland & 9.0 & $26-30$ & 15.0 \\
\hline Spain & 3.3 & 31 and more & 11.9 \\
\hline Italy & 2.1 & \multicolumn{2}{c|}{ Gender } \\
\hline Germany & 1.7 & Female & 66.7 \\
\hline Latvia & 1.2 & Male & 33.3 \\
\hline Russia & 1.2 & \multicolumn{1}{c|}{ Level of education } \\
\hline Turkey & 1.2 & Primary school & 0.5 \\
\hline France & 1.0 & Secondary school & 18.3 \\
\hline Other & 13.1 & Higher education & 80.2 \\
\hline Accompanying person during travel & Other & 1.0 \\
\hline Friends & 46.0 & \multicolumn{2}{c|}{ Employment } \\
\hline Family & 15.5 & Student & 69.5 \\
\hline Alone & 9.0 & Employed & 25.0 \\
\hline Group of tourists & 1.7 & Unemployed & 4.0 \\
\hline Other & 3.6 & Other & 1.4 \\
\hline
\end{tabular}

Source: Research results 
ToSEE - Tourism in Southern and Eastern Europe, Vol. 5, pp. 405-417, 2019

D. Lončarić, J. Dlačić, A. Pisnik: ATTRACTING YOUNG TRAVELLERS TO A TOURIST ...

Respondents profile indicates that Millennials in our research sample $(\mathrm{N}=420)$ are represented as following, come from Croatia (42.9\%) or Austria (23.3\%), mostly travel with friends (46\%), have 20-25 years $(67.6 \%)$, are female $(66.7 \%)$ and students $(69.5 \%)$ with finished higher education $(80.2 \%)$.

Following from stated research objectives, firstly we explored destinations which Millennials consider their dream destinations and which they wish to visit in the future. Performing content analysis on dream destinations 392 responses were identified as some of them $(\mathrm{N}=28)$ didn't pointed out some specific destination like "there are too many places in the world I dream to visit", "doesn't matter where I go as long as I travel", "there are many beautiful different countries" or "every country that has sea and beautiful beaches". Also, some respondents $(\mathrm{N}=20)$, identified multiple destinations like "Croatia and Scandinavia", "Sri lanka and Vietnam" or "Thailand and Dubai". Consequently, these answers were excluded as not possible to relate to specific destination and our analysis continued with 372 respondents. In classifying destinations UNWTO (2017) criteria was used. The results are presented in Table 2.

Table 2: Tourist dream destination by region

\begin{tabular}{|l|c|c|}
\hline \multirow{2}{*}{ DESTINATION/REGION } & \multicolumn{2}{|c|}{ RESPONDENTS } \\
\cline { 2 - 3 } & Frequency & $\%$ \\
\hline Southern/Medit. Europe & 70 & 16.7 \\
\hline South-East Asia & 56 & 13.3 \\
\hline North America & 52 & 12.4 \\
\hline Central/Eastern Europe & 48 & 11.4 \\
\hline Oceania & 35 & 8.3 \\
\hline Caribbean & 26 & 6.2 \\
\hline Western Europe & 19 & 4.5 \\
\hline South America & 16 & 3.8 \\
\hline Sub-Saharan Africa & 13 & 3.1 \\
\hline North Africa & 11 & 2.6 \\
\hline Northern Europe & 10 & 2.4 \\
\hline South Asia & 7 & 1.7 \\
\hline North-East Asia & 5 & 1.2 \\
\hline Middle East & 4 & 1.0 \\
\hline More than one country & 20 & 4.8 \\
\hline No answer & 28 & 6.7 \\
\hline
\end{tabular}

Source: Research results

From previous Table 2 it is evident that the most popular dream destination are countries in Southern and Mediterranean Europe (16.7\%) like Italy $(\mathrm{N}=23)$, Spain $(\mathrm{N}=21)$, Greece $(\mathrm{N}=17)$, Portugal $(\mathrm{N}=5)$ and one answer for other countries like Montenegro, Malta and Canary Islands. Second largest dream destination for Millennials is South-east Asia $(13.3 \%)$ with Maldives $(\mathrm{N}=18)$, Thailand $(\mathrm{N}=13)$ and Japan $(\mathrm{N}=9)$. Other countries have smaller number of answers but dream destinations mentioned are Bali, Indonesia, Vietnam, Malesia, Myanmar and Philippines. While in North America group (12.4\%) dominant dream destination is USA $(\mathrm{N}=25)$ with pointing out several destinations like Hawaii $(\mathrm{N}=11)$ and some cities like New York or Los Angeles. It is interesting that even if research was mainly conducted on Croatian Millennials (see Table 1, 42.9\% of total 
ToSEE - Tourism in Southern and Eastern Europe, Vol. 5, pp. 405-417, 2019

D. Lončarić, J. Dlačić, A. Pisnik: ATTRACTING YOUNG TRAVELLERS TO A TOURIST

sample) around $75 \%$ of respondents in category Central/Eastern Europe indicated that their dream destination is Croatia.

Identifying pull factors for Millennials from dream destinations, second research objective, pointed out 530 different respondent's answers. Several respondents mentioned two or up to six factors that are the reasons for a specific destination to become their dream destination. Results are presented in Table 3.

Table3: Reasons for dreaming about specific tourist destination

\begin{tabular}{|l|c|c|}
\hline \multirow{2}{*}{ CHARACTERISTICS } & \multicolumn{2}{|c|}{ RESPONDENTS } \\
\cline { 2 - 3 } & Frequency & Percentage \\
\hline Beautiful nature & 103 & $15.25 \%$ \\
\hline Culture & 97 & $14.35 \%$ \\
\hline Sea \& sun & 71 & $10.50 \%$ \\
\hline Architecture & 57 & $8.43 \%$ \\
\hline Climate & 49 & $7.25 \%$ \\
\hline People (relaxed, friendly) & 39 & $5.77 \%$ \\
\hline Food & 38 & $5.62 \%$ \\
\hline History & 28 & $4.14 \%$ \\
\hline Tourist offer & 26 & $3.85 \%$ \\
\hline Way of life & 22 & $3.25 \%$ \\
\hline
\end{tabular}

Source: Research results

From previous table (Table 3) it is evident that beautiful nature is dominant reason for dreaming about tourist destination $(15.25 \%)$. Respondents point out characteristics like "beautiful beaches", "clean nature", "I like the scenery", "interesting nature", "sea, beaches and beautiful places", "beautiful diversified landscape, warm weather all year", "because it has everything a person would look for mountains and sea". Second most mentioned category of reasons for dreaming is culture with $14.35 \%$. Respondents point out "because I want to try new things and their culture", "video games are part of their culture", "because of specific culture". But culture is seldom mentioned alone. In majority of the answers it is related to nature, food and history like "cultural diversity, unique nature \& wildlife", "the sea, food, culture", "diverse landscape, inexpensive, good food, culture, beaches". Also, respondents pointed out several categories related to local inhabitants like people are relaxed and friendly $(5.77 \%)$ or way of life $(3.25 \%)$.

To categorize these answers, we used Kapferer (2008) methodology and grouped respondents answers to six categories according to brand identity prism. Several respondents $(\mathrm{N}=71)$ have not pointed out what in tourist destination is motivating them to dream about it. Other answers are grouped into physical attributes, destination image, benefits, achievements, social and cultural interactions. Results are presented in Table 4. 
ToSEE - Tourism in Southern and Eastern Europe, Vol. 5, pp. 405-417, 2019

D. Lončarić, J. Dlačić, A. Pisnik: ATTRACTING YOUNG TRAVELLERS TO A TOURIST ...

Table 4: Reasons for choosing a dream destination

\begin{tabular}{|l|c|c|}
\hline \multirow{2}{*}{ CHARACTERISTICS } & RESPONDENTS \\
\cline { 2 - 3 } & Frequency & $\%$ \\
\hline \multicolumn{3}{|c|}{ Destination-oriented attributes } \\
\hline Physical attributes & 164 & 39.0 \\
\hline Destination image & 8 & 1.9 \\
\hline \multicolumn{3}{|c|}{ Personally-oriented attributes } \\
\hline Benefits & 56 & 13.3 \\
\hline Achievements & 2 & 0.5 \\
\hline \multicolumn{3}{|c|}{ Socially-oriented attributes } \\
\hline Social interactions & 11 & 2.6 \\
\hline Cultural interactions & 97 & 23.1 \\
\hline No reason was given & 71 & 16.9 \\
\hline
\end{tabular}

Source: Research results

From previous table it is evident that physical attributes (39\%), and cultural interactions $(23.1 \%)$ dominate in reasons for dreaming of a specific tourist destination. That is, they represent the majority of pull factors for Millennials when dreaming about a destination. They are followed by perceived benefits in a dream destination (13.3\%). Hence, destination-oriented attributes represent $40.9 \%$ of motivation for Millennials to dream about specific destination. They are followed by socially-oriented attributes that represent $25.7 \%$ of pull factors from Millennials dream destination.

Additionally, we analysed importance of different pull factors that is reasons for choosing a dream destination, across different dream destinations. Results are presented in Table 5.

Table 5: Importance of facets of tourism experience by dream destination (\% of respondents answers)

\begin{tabular}{|c|c|c|c|c|c|c|}
\hline & \multicolumn{6}{|c|}{ DESTINATION FACETS } \\
\hline DESTINATION & $\begin{array}{c}\text { Physical } \\
\text { attributes }\end{array}$ & $\begin{array}{c}\text { Destination } \\
\text { image }\end{array}$ & Benefits & Achievements & $\begin{array}{c}\text { Social } \\
\text { interactions }\end{array}$ & $\begin{array}{c}\text { Cultural } \\
\text { interactions }\end{array}$ \\
\hline $\begin{array}{l}\text { Northern } \\
\text { Europe }\end{array}$ & $77.8 \%$ & & $22.2 \%$ & & & \\
\hline Western Europe & $7.1 \%$ & & $35.7 \%$ & & $7.1 \%$ & $50.0 \%$ \\
\hline $\begin{array}{l}\text { Central/Eastern } \\
\text { Europe }\end{array}$ & $65.1 \%$ & & $16.3 \%$ & & & $18.6 \%$ \\
\hline $\begin{array}{l}\text { Southern/Medit. } \\
\text { Europe }\end{array}$ & $46.0 \%$ & & $12.7 \%$ & & $1.6 \%$ & $39.7 \%$ \\
\hline North America & $39.5 \%$ & $7.9 \%$ & $23.7 \%$ & & $5.3 \%$ & $23.7 \%$ \\
\hline Caribbean & $33.3 \%$ & $4.2 \%$ & $16.7 \%$ & & $4.2 \%$ & $41.7 \%$ \\
\hline South America & $58.3 \%$ & & & & $16.7 \%$ & $25.0 \%$ \\
\hline Middle East & $100.0 \%$ & & & & & \\
\hline North Africa & $20.0 \%$ & & $10.0 \%$ & & & $70.0 \%$ \\
\hline $\begin{array}{l}\text { Sub-Saharan } \\
\text { Africa }\end{array}$ & $54.5 \%$ & & $9.1 \%$ & & $18.2 \%$ & $18.2 \%$ \\
\hline North-East Asia & $60.0 \%$ & & & $20.0 \%$ & & $20.0 \%$ \\
\hline South-East Asia & $54.2 \%$ & $2.1 \%$ & $16.7 \%$ & $2.1 \%$ & & $25.0 \%$ \\
\hline Oceania & $77.8 \%$ & $3.7 \%$ & $7.4 \%$ & & $3.7 \%$ & $7.4 \%$ \\
\hline South Asia & $16.7 \%$ & & $16.7 \%$ & & & $66.7 \%$ \\
\hline All regions & $48.5 \%$ & $2.4 \%$ & $16.6 \%$ & $0.6 \%$ & $3.3 \%$ & $28.7 \%$ \\
\hline
\end{tabular}

Source: Research results 
ToSEE - Tourism in Southern and Eastern Europe, Vol. 5, pp. 405-417, 2019

D. Lončarić, J. Dlačić, A. Pisnik: ATTRACTING YOUNG TRAVELLERS TO A TOURIST ...

Analysis shows that not in all destinations Physical attributes or Cultural interactions are equally present as pull factors in that destination. Also, chi-square results are indicating that are present differences among destinations in importance of pull factors $\left(\chi^{2}(75)=\right.$ 133.253, $\mathrm{p}<0.000)$. Dominant on all regions level are Physical factors $(48.5 \%$ of respondents) following by Cultural interactions (28.7\% of respondents). But in some destinations it is all about that constitutes Millennials dreams related to Physical attributes (Middle East with 100\%, North Europe and Oceania with $77.8 \%$, Central/Eastern Europe with $65.1 \%$, North-East Asia with $60 \%$ or South America with $58.3 \%)$. While Cultural interactions are dominant in North-Africa (70\%), South Asia $(66.7 \%)$ or Western Europe $(50 \%)$. Benefits are not so important but still in some destinations they form respondents dreams like in Western Europe (35.7\%) or North America (23.7\%). Social interactions are most important in Sub Saharan Africa (18.2\% of the respondents). While Destination image is not so important in dreaming about a destination and forms dreams in $7.9 \%$ respondents in North America. Achievements are only important in two destinations North-East Asia (20\% of respondents) and South-East Asia (2.1\%).

Research focused also on third objective, that is to identify ways Millennials search for information and plan their trip. Several characteristics of Millennials behaviour in planning their trip are explored like, daily hours spent on Internet, usage of internet in gathering information while planning a trip, reading comments and number of comments from other individuals that visited that destination and reasons for reading comments and experiences. Results are presented in Table 6.

\section{Table 6: Respondents characteristics related to trip planning}

\begin{tabular}{|c|c|c|}
\hline CHARACTERISTICS & Frequency & Percentage \\
\hline \multicolumn{3}{|l|}{ Daily hours spend on the Internet } \\
\hline Less than $30 \mathrm{~min}$ & 11 & 2.6 \\
\hline 30 min to 1 hour & 47 & 11.2 \\
\hline 1 to 3 hours & 162 & 38.6 \\
\hline 3 hours and more & 200 & 47.6 \\
\hline \multicolumn{3}{|c|}{ Usage of internet in gathering information in planning a trip } \\
\hline Always & 308 & 73.3 \\
\hline Occasionally & 104 & 24.8 \\
\hline Do not & 8 & 1.9 \\
\hline \multicolumn{3}{|c|}{ Reading experiences and comments on tourist destination } \\
\hline Always & 209 & 49.8 \\
\hline Occasionally & 191 & 45.5 \\
\hline Do not & 20 & 4.8 \\
\hline \multicolumn{3}{|c|}{ Reasons for reading experiences and comments on tourist destination } \\
\hline To collect information needed to make a purchase or travel decision & 129 & 30.7 \\
\hline Because I want to hear first-hand experience. & 88 & 21.0 \\
\hline $\begin{array}{l}\text { After I have made a purchase decision to know what to expect from } \\
\text { the tourist product or service }\end{array}$ & 47 & 11.2 \\
\hline $\begin{array}{l}\text { Out of curiosity (even though I have no intention of traveling, or am } \\
\text { not able to travel in the near future) }\end{array}$ & 25 & 6.0 \\
\hline
\end{tabular}


ToSEE - Tourism in Southern and Eastern Europe, Vol. 5, pp. 405-417, 2019

D. Lončarić, J. Dlačić, A. Pisnik: ATTRACTING YOUNG TRAVELLERS TO A TOURIST ...

\begin{tabular}{|l|c|c|}
\hline CHARACTERISTICS & Frequency & Percentage \\
\hline I am not interested in the comments and experiences of others. & 14 & 3.3 \\
\hline Unspecified reason Number of comments read in planning a trip \\
\hline \multicolumn{2}{|c|}{117} & 27.8 \\
\hline Up to 5 comments & 94 & 22.4 \\
\hline Between 6 and 20 comments & 162 & 38.6 \\
\hline More than 20 comments & 40 & 9.5 \\
\hline Unspecified number & 124 & 29.5 \\
\hline
\end{tabular}

Source: Research results

Millennials, according to our research, spend on average 3 hours and more per day on Internet $(47.6 \%)$ or 1 to 3 hours per day $(38.6 \%)$. In planning a trip phase, they always use Internet in gathering information $(73.3 \%)$, they always $(49.8 \%)$ or occasionally $(45.5 \%)$ read experiences and comments of other Internet users regarding travel and tourist facilities, they read between 6 and 20 comments $(38.6 \%)$ when gathering information from informal communication sources. Respondents read experiences and comments of other Internet users regarding travel and tourist facilities: to collect information needed to make a purchase or travel decision $(30.7 \%)$ or because they want a first-hand experience $(21 \%)$.

Also, respondents were asked to select different information sources they use for collecting information about tourist destination. Several possibilities were offered to them. As they had the possibility to select multiple information sources we collected 1540 answers. Hence, indicating that Millennials use different information sources simultaneously. Results are presented in Table 7.

Table 7: Information sources used to gather information in trip planning

\begin{tabular}{|l|c|c|}
\hline INFORMATION SOURCE & Frequency & Percentage \\
\hline Official Website of the destination & 268 & 63.8 \\
\hline Official Website of the hotel and other tourism products & 233 & 55.5 \\
\hline Pinterest & 32 & 7.6 \\
\hline Online forum & 132 & 31.4 \\
\hline Google+ & 41 & 9.8 \\
\hline Facebook & 189 & 45.0 \\
\hline Twitter & 10 & 2.4 \\
\hline Instagram & 105 & 25.0 \\
\hline LinkedIn & 4 & 1.0 \\
\hline Blog & 92 & 21.9 \\
\hline TripAdvisor, Booking.com, etc. & 276 & 65.7 \\
\hline YouTube & 122 & 29.0 \\
\hline News Websites & 36 & 8.6 \\
\hline
\end{tabular}

Source: Research results 
ToSEE - Tourism in Southern and Eastern Europe, Vol. 5, pp. 405-417, 2019

D. Lončarić, J. Dlačić, A. Pisnik: ATTRACTING YOUNG TRAVELLERS TO A TOURIST

Respondents in gathering information use TripAdvisor and Booking.com websites $(65.7 \%)$, official Website of the destination $(63.8 \%)$ and official Website of the hotel and other tourism products $(55.5 \%)$ followed by Facebook $(45 \%)$. The least important information sources while planning a trip are LinkedIn (1\%) and Twitter (2.4\%). To better understand respondents' behaviour they were also asked to explain reasons for reading online reviews. They provided answers on 5-point Likert scale anchored at 1 (strongly disagree) to 5 (strongly agree). Results are presented in Table 8.

Table 8: Reasons for reading information sources to gather information in trip planning

\begin{tabular}{|l|c|c|}
\hline \multicolumn{1}{|c|}{ ITEM } & Mean & SD \\
\hline $\begin{array}{l}\text { I often read other tourists' online travel reviews to know what destinations } \\
\text { make good impressions on others. }\end{array}$ & 3.53 & 1.187 \\
\hline $\begin{array}{l}\text { To make sure I choose the right destination, I often read other tourists' } \\
\text { online travel reviews. }\end{array}$ & 3.50 & 1.208 \\
\hline $\begin{array}{l}\text { I often consult other tourists' online travel reviews to help choose an } \\
\text { attractive destination. }\end{array}$ & 3.11 & 1.209 \\
\hline $\begin{array}{l}\text { I frequently gather information from tourists' online travel reviews before } \\
\text { I travel to certain destination. }\end{array}$ & 3.41 & 1.151 \\
\hline $\begin{array}{l}\text { If I don't read tourists' online travel reviews when I travel to a destination, } \\
\text { I worry about my decision. }\end{array}$ & 2.35 & 1.248 \\
\hline $\begin{array}{l}\text { When I travel to destination, tourists' online travel reviews make me } \\
\text { confident in travelling to a destination. }\end{array}$ & 3.19 & 1.092 \\
\hline
\end{tabular}

Source: Research results

In previous table it is evident that respondents read information sources on Internet to search for destinations that make good impressions on tourists $(\overline{\mathrm{x}}=3.53)$ or to reassure themselves that they made a good decision in selecting a tourist destination $(\overline{\mathrm{x}}=3.50)$ they want to visit.

\section{DISCUSSION AND CONCLUSION}

Research results indicate that Millennials consider mostly destinations in Southern/Mediterranean Europe as their dream destinations which is contrary to the research of Morgan and $\mathrm{Xu}$ (2009), who found that only $2 \%$ of British students dream about Mediterranean destinations. They are followed by South-East Asia and North America. In determining pull factors to that dream destinations the most important are destination-oriented attributes like physical attributes of the destination (beautiful nature and sea $\&$ sun). This pull factors in dream destination are followed by socially-oriented attributes like cultural interactions (specific culture of a destination, architecture, food and history).

Research also indicated that Millennials have different information seeking patterns when planning a trip. They dominantly consider Internet and collect other tourist experiences and to find information about dream destination. For them it is important to read first-hand experience of a destination and find out how destination impressed other 
ToSEE - Tourism in Southern and Eastern Europe, Vol. 5, pp. 405-417, 2019

D. Lončarić, J. Dlačić, A. Pisnik: ATTRACTING YOUNG TRAVELLERS TO A TOURIST

tourists. Different travel websites are important sources of information about dream destination for Millennials alongside with official Website of the destination.

This research contributes in following ways. By indicating importance of different pull factors to a specific destination. Hence, it is not important just to identify pull factors for Millennials but also to acknowledge that between different destinations have different pull factors for Millennials. Also, research contributes in providing an empirical evidence that pre-trip phase in customer journey is an important phase. Marketing managers and destination management organizations should take care about tourists also in their phase of dream destination. In this dream phase opinions and comments found on web sites like TripAdvisor and through social media, not necessary just from friends and family, shapes tourist opinion. So, marketing managers in a tourist destination have to be aware that pre-trip planning is equally important as services they provide in a destination. But, in this pre-trip planning phase travel websites and comments as well as experiences from others are shaping dreams of future visitors. As providing authentic experience is a key driver of Millennials, it should be shaped through online channels by providing authentic experiences of past visitors and emphasising physical aspects of a destination. Also, marketing managers in creating their destination image have to figure out what pulls their target market to visit that destination. As research indicated that Millennials indicated different pull factors for different destinations.

This research as many others has some limitations. First, although the sample consists of Millennials from several countries it does not include all countries in Europe. Further research could focus on broadening the sample to include more Millennials from different countries and to have more gender balanced sample. Also, it would be interesting to explore specific destinations how they are successful in providing information through online channels related to characteristics that Millennials valued as important pull factor for that destination.

\section{ACKNOWLEDGMENT}

This paper has been supported by the University of Rijeka under the project number [uniri-drustv-18-235-1399].

\section{REFERENCES}

Bozic, S., Kennell, J., Vujicic, M.D. and Jovanovic, T. (2017), "Urban tourist motivations: why visit Ljubljana?", International Journal of Tourism Cities, Vol. 3, No. 4, pp. 382-398 https://doi.org/10.1108/IJTC-03-2017-0012

Cetin, G. and Bilgihan, A. (2016), "Components of cultural tourists' experiences in destinations", Current Issues in Tourism, Vol. 19, No. 2, pp. 137-154 http://dx.doi.org/10.1080/13683500.2014.994595

Crompton, J.L. (1979), "Motivations for pleasure vacation", Annals of tourism research, Vol. 6, No. 4, pp. 408-424 https://doi.org/10.1016/0160-7383(79)90004-5

Dlačić, J. and Kadić-Maglajlić, S. (2013), "The Role of Gender and Situational Factors in Wine Consumption of Generation Y”, South East European Journal of Economics and Business, Vol. 8, No. 1, pp. 53 61, https://doi.org/10.2478/jeb-2013-0008 
ToSEE - Tourism in Southern and Eastern Europe, Vol. 5, pp. 405-417, 2019

D. Lončarić, J. Dlačić, A. Pisnik: ATTRACTING YOUNG TRAVELLERS TO A TOURIST

Fratu, D. (2011), "Factors of influence and changes in the tourism consumer behaviour", Bulletin of the Transilvania University of Brașov, Vol. 4, No. 1, pp. 119-126, available http://webbut.unitbv.ro/BU2011/Series\%20V/BULETIN\%20V\%20PDF/20\%20fratu\%201\%20B UT\%202011.pdf

Future foundation (2016), Millennial traveller report, viewed 10 February 2019 , https://www.foresightfactory.co/wp-content/uploads/2016/11/Expedia-Millennial-TravellerReport-Final.pdf

Ho, C.I., Lin, M.H. and Chen, H.M. (2012), "Web users' behavioural patterns of tourism information search: From online to offline", Tourism Management, Vol. 33, No. 6, pp. 1468-1482 https://doi.org/10.1016/j.tourman.2012.01.016

Horner, S. and Swarbrooke, J. (2016), Consumer Behaviour in Tourism, Third edition, Routledge, New York.

Hyde, K.F. (2008), "Information processing and touring planning theory", Annals of Tourism Research, Vol. 35, No. 3, pp. 712-731 https://doi.org/10.1016/j.annals.2008.05.001

ITB World Travel Trends Report 2016/2017, Messe Berlin, viewed 9 April 2018, https://www.itbberlin.de/media/itb/itb_dl_all/itb_presse_all/World_Travel_Trends_Report_2016_2017.pdf

Jacobsen, J.K.S. and Munar, A.M. (2012), "Tourist information search and destination choice in a digital age", Tourism Management Perspectives, Vol. 1, No. 1, pp. 39-47 https://doi.org/10.1016/j.tmp.2011.12.005

Jalilvand, M.R., Ebrahimi, A. and Samiei, N. (2013), "Electronic word of mouth effects on tourists' attitudes toward Islamic destinations and travel intention: An empirical study in Iran", Procedia-Social and Behavioral Sciences, Vol. 81, pp. 484-489 https://doi.org/10.1016/j.sbspro.2013.06.465

Kapferer, J. N. (2012), The new strategic brand management: advanced insights and strategic thinking, 5th edition, Kogan page publishers, London, UK.

Kapferer, J.N. (2008), The new strategic brand management: Creating and sustaining brand equity long term, Kogan Page Publishers, London and Philadelphia.

Karayilan, E. and Cetin, G. (2016), "Tourism Destination: Design of Experiences", in Sotiriadis, M. and Gursoy, D. (Eds.), The Handbook of Managing and Marketing Tourism Experiences, Emerald Group Publishing, UK, pp. 45-65.

Monaco, S. (2018) "Tourism and the new generations: emerging trends and social implications in Italy", Journal of Tourism Futures, Vol. 4, No. 1, pp. 7-15 https://doi.org/10.1108/JTF-12-2017-0053

Morgan, M. (2008), "What makes a good festival? Understanding the event experience", Event Management, Vol. 12, No. 2, pp. 81-93 https://doi.org/10.3727/152599509787992562

Morgan, M. and Xu, F. (2009), "Student travel experiences: Memories and dreams", Journal of Hospitality Marketing \& Management, Vol. 18, No. 2-3, pp. 216-236 https://doi.org/10.1080/19368620802591967

Moutinho, L. (2000), Strategic Management in Tourism, CABI Publishing, Wallingford.

Munar, A.M. and Jacobsen, J.K.S. (2014), "Motivations for sharing tourism experiences through social media", Tourism management, Vol. 43, pp. 46-54 https://doi.org/10.1016/j.tourman.2014.01.012

Oh, H. C., Uysal, M. and Weaver, P. A. (1995), "Product Bundles and Market Segments Based on Travel Motivations: A Canonical Correlation Approach", International Journal Hospitality Management, Vol. 14, No. 2, pp. 123-137 https://doi.org/10.1016/0278-4319(95)00010-A

Otto, J. E. and Ritchie, J. B. (1996), "The service experience in tourism", Tourism management, Vol. 17, No 3, pp. 165-174 https://doi.org/10.1016/0261-5177(96)00003-9

Pesonen, J., Komppula, R., Kronenberg, C. and Peters, M. (2011), "Understanding the relationship between push and pull motivations in rural tourism", Tourism Review, Vol. 66, No. 3, pp. 32-49 https://doi.org/10.1108/16605371111175311

Turnbull, D. R. and Uysal, M. (1995), “An Exploratory Study of German Visitors to the Caribbean: Push and Pull Motivations", Journal of Travel and Tourism Marketing, Vol. 4, No. 2, pp. 85-92 https://doi.org/10.1300/J073v04n02 07

Uysal, M. and Jurowski, C. (1994), “Testing the Push and Pull Factors”, Annals of Tourism Research, Vol. 21, No. 4, pp. 844-846 https://doi.org/10.1016/0160-7383(94)90091-4

World Tourism organization UNWTO Tourism Highlights: 2017 Edition, viewed 9 March 2017, https://www.e-unwto.org/doi/pdf/10.18111/9789284419029

Xu, F., Morgan, M. and Song, P. (2009), "Students' travel behaviour: a cross-cultural comparison of UK and China”, International Journal of Tourism Research, Vol. 11, No. 3, pp. 255-268 https://doi.org/10.1002/jtr.686

Yuan, S., and C. McDonald (1990), "Motivational Determinates of International Pleasure Travel", Journal Tourism Research, Vol. 29, No. 1, pp. 42-44 https://doi.org/10.1177/004728759002900109 
ToSEE - Tourism in Southern and Eastern Europe, Vol. 5, pp. 405-417, 2019 D. Lončarić, J. Dlačić, A. Pisnik: ATTRACTING YOUNG TRAVELLERS TO A TOURIST ...

Dina Lončarić, $\mathrm{PhD}$, Associate Professor

University of Rijeka, Faculty of Tourism and Hospitality Management

Primorska 42, P.P. 97, 51410 Opatija, Croatia

Phone: ++385 51 294187, Fax: ++385 51291965

E-mail: dina.loncaric@fthm.hr

Jasmina Dlačić, $\mathrm{PhD}$, Assistant Professor

University of Rijeka, Faculty of Economics and Business

Ivana Filipovića 4, 51000 Rijeka

Phone: ++385 51355 111, Fax: ++385 51212268

E-mail: jasmina.dlacic@efri.hr

Aleksandra Pisnik, $\mathrm{PhD}$, Associate Professor

University of Maribor, Faculty of Economics and Business

Razlagova 14, 2000 Maribor, Slovenia

Phone: +38622290342

E-mail: aleksandra.pisnik@um.si 